\title{
Household Fuelwood Consumption Impact on Forest Degradation in The Case of Motta District, Northwest Ethiopia
}

\author{
Mulatu Mengist Ferede \\ Ethiopian Environment and Forest Research Institute \\ P.O.Box: 24536 code 1000 Addis Ababa, Ethiopia
}

\begin{abstract}
Traditional energy sources like fuelwood, charcoal, cow dung, and crop residue are common for household domestic energy consumption in the majority people of the study area as well as in Ethiopia. However, information related the impact of household fuelwood consumption on forest degradation is limited in the study area. Therefore, the aim of this study was to examine the impacts on households' domestic fuelwood consumption on deforestation and forest degradation in Motta district northwest Ethiopia. A random sampling procedure was employed to select 140 sample households involved in the household survey. Then open ended and close ended semi structured questioners were provide for each sample household. In addition, sample bundle of fire wood and sack of charcoal were measured to quantify households' traditional measuring unit into standardize biomass unit. Descriptive statistics and multiple linear regression was performed to examine household fuelwood impact on forest degradation and for identifying main determinant factors affecting households' daily fuelwood consumption. . The result revealed that farmers owned plantation is the main source of fuelwood consumption a species like Eucalyptus globulus. Annually they consumed $2.36 \mathrm{~kg} /$ household. Hence, the total communities consumption was around 3,635.51ton dried biomass of fuelwood which is estimated about 1.89 hectare of forest land is degraded due to households' domestic energy consumption in the study area. The statistical regression analysis also revealed family size and their residence far from fuelwood source had statistically significant different. It is confirmed that household fuelwood consumption had negatively impact of forest resource development and accelerate deforestation and forest degradation rate. Hence, in order to solve deforestation and forest degradation due to forest dependence energy consumption; providing other alternative energy accessibility like electricity, solar energy, biogas, improved cook stove are recommended.
\end{abstract}

Keywords: Fuelwood, Charcoal, Forest degradation, Household energy, Household

DOI: $10.7176 / \mathrm{JETP} / 10-4-02$

Publication date: August $31^{\text {st }} 2020$

\section{Introduction}

Woody biomass is one of the main sources of domestic energy by satisfying the growing energy demand of Africa people /developing countries (cities). Almost half of the world's population and nearly $81 \%$ of Sub-Saharan Africa (SSA) depend on woody biomass energy especially for cooking, household, heating and other homestead activities (AFREAP, 2011). In global context about 55\% of the wood extracted from forests is which is responsible for 5\% of global deforestation (Miles and Dickson, 2010), while; in developing countries the consumption of fuelwood account more than $75 \%$ of wood harvested from forest is used as domestic fuelwood purpose (Bearer et al., 2008). Increasing consumption of fuelwood has caused in an approaching crisis in scarcity of fuelwood in world (Macht and Axinn, 2007). The Consumption of traditional fuels has negative environmental, economic and health impacts on local communities as well as the worldwide, That leads to deforestation and forest degradation following ecological imbalance and increasing the use of agricultural residues and animal dung deprives the land of essential nutrients necessary for soil fertility (Geissler et al., 2013).

In Ethiopia traditional biomass consumption (fuelwood, charcoal, dung, and crop residue) in household's level accounts approximately $90 \%$ of total primary energy use (Mekonnen and Köhlin, 2009). Inline with this biomass is the major source of cooking fuel for urban and rural house hold which accounts about $84 \%$ and $99 \%$ from the total energy consumption, respectively (MEFCC, 2016). Currently, most of Ethiopian households depend overwhelmingly on biomass for cooking in rural areas and even in most urban areas households have upgraded their biomass use (Damte et al., 2012).

In recent years peoples who lived in urban areas starting uses of electricity as a source of energy but still there is higher biomass fuelwood consumption like charcoal, branches and leaves which accounts more than 105172465 ton/yr; from 2000 to 2013 the charcoal demanding of the country increased from 48,581 to 4,132,873 tons/year (Geissler et al., 2013). This indicate that household domestic fuelwood consumption has a great impacts on changes of forest land cover type (Negasi et al., 2018). Similarly, the growing demand of fuel wood as source of enegry increase the rate of forest degradation and deforestation in the country. (Berhanu et al., 2017).

Socioeconomics characteristics, environmental characteristics and technology affected the household's fuelwood consumption. Household size is a significant variable that directly influence fuelwood consumption (Mekonnen, 1997, Mitku and Yi, 2020). Household's residence far from fuel source negatively affected the daily 
fuelwood consumptions, the people who lived in sufficient available fuel wood area or nearby forest relatively consumed higher fuel wood as compared to the other. (Ullah and Tani, 2017). However, studies related to the impact of household fuel wood consumption on forest deforestation and degradation is limited in the study area.

Therefore, this study design to examine the households' domestic fuelwood consumption for cooking and heating consumption impact on forest degradation and deforestation in study area, North West Ethiopia., It is expected to quantifying household mean daily woody biomass consumption and estimating the amount of forest depletion annually for domestic energy purpose. It also provide information for policy makers, governmental and nongovernmental organization which are working on afforestation and reforestation, Environmental protection, energy conservation program, and suggest other source of energy to decrease the pressure on forest for fuelwood purpose in the study area as well as the reference for all over Ethiopia.

\section{Methods and Materials}

\subsection{Study area}

The study was conducted in northwest Ethiopia Amhara Regional State East gojjam zone in Motta district specifically Sedie woreda Andnet Mariyam kebelle ${ }^{1}$, which is about $373 \mathrm{Km}$ from the Capital city of Ethiopia, Addis Ababa. Geographically: UTM (1104'47"N - 11007'40"N latitude and 37036'38"E - 370 45'00"E) longitude with altitude of $1800 \mathrm{~m}$ a.m.s. (Figure-1). It has mostly two agro-ecological zones, namely Woina-Dega Dega Two main seasons characterize the study site. The first one is long rainy season which lasts from June to end of September and locally known as Kiremt. The second known as Bega, it is the rest of months and it is the season where the main harvest and land preparation activities have been practiced. The short rain at this season from March to May is very important for planting and sowing crop. The land use pattern is under categorized of cultivated, grazing, forests and shrubs, residence and others, and non- utilized respectively in the district. Livestock, crops and forest products are the mains ources farmers income. Zea mays, Eragrostis tef, Triticum, Lens culinaris, Hordeum vulgare, Glycine max, and Sorghum bicolor are crops that mainly grown in the study area under rain fed conditions. Livestock's also the main integral components of the farming system and fixed assets. Sheep, Goat, Chickens and Cattle, Donkey, Horse, and Mule. Forests and shrubs which dominantly Eucalyptus globulus plantation, Acacia decurrens, Acacia abyssinica, Cupressus lustitanica and from natural forest both shrubs and trees.

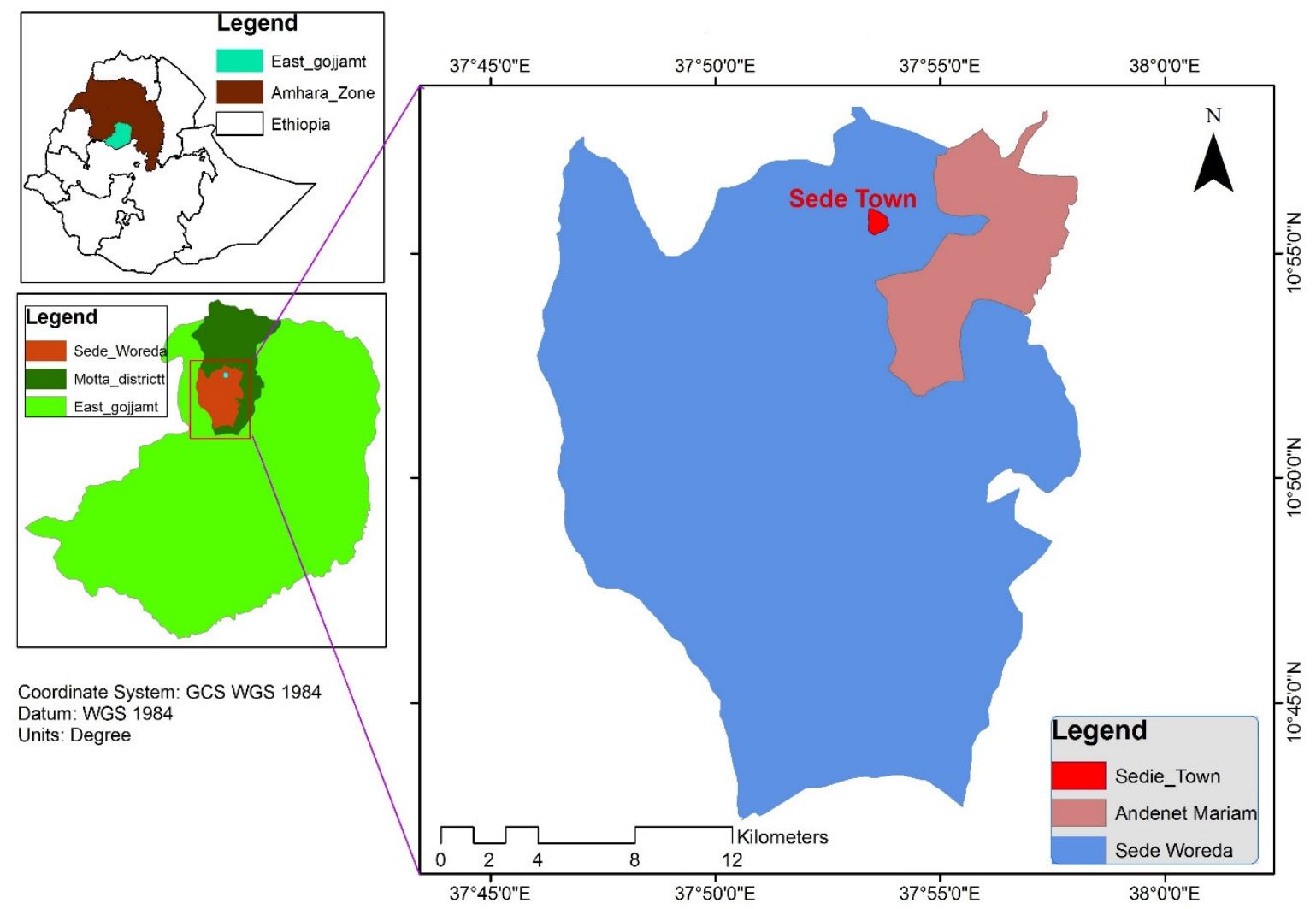

Figure 1. Map of the study area Motta district Sedie woreda Andinet Mariam kebele

\footnotetext{
${ }^{1}$ Kebelle is the smallest administration unit in Ethiopia
} 


\subsection{Sampling techniques and sample size}

The purposive sampling method was employed to obtain sample kebeles, in which there was successive selection of the household within the population. Sample household selection was done according to simplified formula provided by Yamane (1967) and revised by (Israel, 2012). There were 1353 total household in the kebelle. Accordingly; the sample households from target population at $92 \%$, confidence level $0.08(8 \%)$ level of precision. .Totally 140 households were conducted to get the required data.

$$
n=\frac{N}{1+N(e)^{2}}
$$

Where $\mathrm{n}$ is the sample size, $\mathrm{N}$ is the population size, and e is the level of precision at $92 \%$ at significance level 0.08 .

\subsection{Data sources}

For this study, both primary and secondary data sources were collected in the form of quantitative and qualitative information. Primary data was collected through a household survey, focus group discussion, and key informant interview in the form of open and close-ended questioners were provided by the local language Amharic. Information such as household socioeconomic characteristics, mean daily fuelwood and charcoal consumption, most commonly used tree species for domestic energy use, source of fuelwood, field observation was done and crossed checked survey data by focus group discussion and key informant interview. Secondary data was collected from Woreda administration offices and Kebelle agriculture office, and reviewing literatures from published and unpublished materials that supported the finding of this study.

\subsection{Variables and model specification}

Based on the main aim study the impact of households' fuelwood consumption on forest degradation and increasing deforestation rate multiple linear econometrics model on households' mean daily fuelwood consumption was analyzed statistically by using STATA software.

\subsubsection{Variables}

Dependent variable: It is a continuous variable in mass of mean daily fuelwood of both fire wood and charcoal consumption in kilogram. The households' fuel wood consumption was found by questioner survey directly for each individual households in terms of local measurement unit bundle of fire wood and sack of charcoal. Then to convert the equivalent biomass by taking 70 bundles of fire wood and 50 sack of charcoal in local market weighted in kilogram for calculating the mean daily consumption dried biomass for each households. The determinant factors of households fuelwood consumption shown below and expected effect (Table.1)

Independent variables: The explanatory variable in this test are household's socioeconomics characteristics and other determinant factors in household daily fuelwood consumption. Household's socioeconomics characteristics like Sex, age, education status, family size, residence far from fuelwood source may have significance difference on perception regarding fuel wood extraction and environment degradation (Ullah and Tani, 2017, Mitku and Yi, 2020).

Table 1. Independent variables, their description, type and expected effects on linear model

\begin{tabular}{|l|l|l|l|}
\hline Variables & Description & Type & Expect effect \\
\hline FWCON & HH Fuelwood Consumption in KG & Continuous & Dependent Variable \\
\hline Sex HHH & Sex Of HH Female=0 Male=1 & Dummy & $+/$-ve \\
\hline Age HHH & Age of HHH in Years & Continuous & $+/$-ve \\
\hline EDUC & Schooling years HHH & Continuous & - ve \\
\hline HHSize & Number of people in HH & Continuous & + ve \\
\hline DISFWS & Distance from home to fuelwood source & Continuous & -ve \\
\hline
\end{tabular}

\section{HHH: household headed}

\subsubsection{Model specification}

Statistically analyzing the impact of explanatory variables on household fuelwood consumption econometrics model builds as follow.

$$
\mathrm{FWC}=\beta 0++\beta 1(\mathrm{SEX})+\beta 2(\text { Age })+\beta 3(\text { Hsize })+\beta 4(\text { Educ })+\beta 5(\text { DFWS })+\varepsilon
$$

Where, FWC is dependent variables denoted mean daily household fuelwood consumption

Sex $=$ Sex of the household headed $(1=$ male, $0=$ female $)$

Age $=$ Age of the household headed (year)

Hsize $=$ Number of person live in one households $(\mathrm{N})$

Educ $=$ Educational status of the household headed in schooling year

DFWS $=$ Households residence from fuelwood source $(\mathrm{km})$

" $\mathrm{Bi}$ " is vector parameters to be estimated. 
" $\beta 0$ " is the constant term, and

" $\varepsilon$ " is the error term

\section{Results}

\subsection{Household characteristics}

The data from the household survey revealed that $82.86 \%$ the respondents' were male-headed households, and the rest $17.14 \%$ were female-headed, the mean age of the household headed was 43.16 year with a range of $29-68$ years old, the average family size in one household was 4.82 person with 2 and 8 person minimum and maximum respectively, the educational status of a household headed by schooling year averagely was 2.99 with the range of 0 - 10 years minimum and maximum schooling years, and the households settlement far from the main fuelwood source that is either plantation of natural forest averagely was found 1.25 kilometer with the range of $0.35-5.5 \mathrm{~km}$ in the study area(Table.2).

Table 2. Summary of households' characteristics

\begin{tabular}{|l|l|l|l|l|l|l|}
\hline Variable & Observation & Percent & Mean & Std. Dev. & Min & Max \\
\hline HHH Sex & 140 & 100 & & - & - & - \\
\hline Male & 111 & 79.29 & - & - & - & - \\
\hline Female & 20.71 & 20.71 & & & & - \\
\hline HHH Age (Yr.) & 140 & - & 45.58 & 12.03 & 26 & 71 \\
\hline Fam size(N) & 140 & - & 5.94 & 2.03 & 2 & 10 \\
\hline HHH Education (yr.) & 140 & - & 2.99 & 2.19 & 0 & 10 \\
\hline Distance from fuelwood source(Km) & 140 & - & 2.82 & 1.29 & 0.5 & 5.5 \\
\hline
\end{tabular}

\subsection{Household fuelwood consumption}

Based on the results found from household's survey the mean daily firewood consumption per household was 6.45 $\mathrm{kg}$ dried biomass which indicates the annual fuelwood consumptions per household was 2,361.55 kg/household's equivalent about 2.36 ton. Accordingly; the total fire wood consumption of all households in the study area found about 3,193.08ton dried biomass.

Charcoal is also another forest dependence households' domestic energy source, which isn't most common in the study area. Some households used charcoal for only coffee and tea making purpose. The result from household survey revealed that the mean annual charcoal consumption of the household was two sacks, which is equivalent to $60 \mathrm{~kg}$ of charcoal. According to Rensselear (2010) report to produce $1 \mathrm{~kg}$ of charcoal needs $5.45 \mathrm{~kg}$ of wood biomass. Hence, $327 \mathrm{~kg}$ of dried biomass is needed to produce $60 \mathrm{~kg}$ of charcoal .Accordingly; the dried biomass consumption in the study area to be estimated $442,431 \mathrm{~kg}$ (442.43ton). In general, the total households' fuelwood biomass consumption in the study area was found about 3,635.51ton of dried biomass for fire wood and charcoal. (442.43ton). Finally, the total households' fuelwood biomass consumption in the study area was found about 3,635.51ton of dried biomass both from fire wood and charcoal.

\subsection{Fuelwood impact on forest degradation}

The estimation of forest depletion was calculated by considering the most common tree species used for fuelwood purposes in the study area that is Eucalyptus globulus. In Ethiopia most people are dependent on Eucalyptus tree species as a source of fuelwood (Teketay, 2000). According to Tatek et al. (2018) on Comparative growth performance study of fast-growing tree species for wood fuel production in highland area of Ethiopia Eucalyptus globulus was the one which planted by $1.5 \times 1.5 \mathrm{~m}$ shown good growth performance with $86 \%$ survival rate. Furthermore; it indicates that Eucalyptus globulus can planted for fuelwood purpose 4,489 tree/hectare. Out of this assume $70 \%$ of the trees will become matured, and expected to be 3,142 trees per hectare.

Hence, the result found from household survey was 3,635.51 ton dried biomass for local communities' fuelwood consumption. As workr of Fantu (2005) revealed that dry matter of above ground biomass (AGB) single tree including components of stem wood, branch, foliage, and bark of Eucalyptus globulus was found $613 \mathrm{~kg} / \mathrm{tree}$ with a diameter at breast height and height range of 15-34 cm and 18.8-43.6 m respectively. Consequently, annually forest deforested area for domestic households' fuelwood consumption to be estimated around 5931 matured tree, which is equivalent to about 1.89 hectare/year Eucalyptus globulus plantation forest in the study area. Similarly, Berhanu et al. (2017) indicates in south western Ethiopia fuel wood utilization impacts on forest resources implied that 1.76 ha of forest resources was consumed per annum for fuel wood by the community members.

\section{'ZA2ZA}

The multiple linear regression result indicated that male household headed have consumed more fuelwood than female headed, family size has positively relationship with fuelwood consumption, while Age, Education level and households residence far from main fuelwood source have negatively relkationship with daily fuelwood consumption. Unfortunately, only family size and household's residence distance from main fuelwood source had 
statically significant difference on fuelwood consumption between the sample households and the proportion of the variation in dependent variable explained by explanatory variables(R-squared) is $0.6930(69.3 \%)$. household family size has positive relationship, education level and distance to sources of fuel wood collection had negative relationship to fuel wood consumption of household (Kasim et al., 2020).

The result obtained from the linear regression model indicated that the number of people live in the $\mathrm{HH}$ had a statistically highly significant difference at $(\mathrm{p}<1 \%$ ) level of significance (Table. 3$)$. The result suggests that the fuelwood consumption of households' with one more person living in the family will be increased by about $0.94 \mathrm{~kg}$ fuelwood biomass per day which have a direct relationship with each other (Figure-2).

The distance from the residence of the household to fuelwood source had statistically significant effect on the household's fuelwood consumption at a significance level $(\mathrm{p}<5 \%)$ (Table. 3) The result further indicate that as the distance from the residence of the household to fuelwood source increased by one kilometer, the household fuelwood consumption decrease by $0.19 \mathrm{~kg}$ of wood in daily consumption. The dependent and independent variable had negatively relationship (Figure-3).

Table 3. Multiple linear regression model

\begin{tabular}{lllllll}
\hline fuelwoodco $\sim \mathrm{n}$ & Coef. & Std. Err. & $\mathrm{t}$ & $\mathrm{P}>\mathrm{t}$ & \multicolumn{2}{l}{ [95\% Conf. Interval } \\
\hline HHHsex & 0.384486 & 0.262383 & 1.47 & 0.145 & -0.13446 & 0.903433 \\
HHHage & -0.01973 & 0.013228 & -1.49 & 0.138 & -0.0459 & 0.006428 \\
Famsize & 0.939516 & 0.08291 & 11.33 & $0.000^{* * *}$ & 0.775535 & 1.103497 \\
Education & $-6.6 \mathrm{E}-05$ & 0.048734 & 0.00 & 0.999 & -0.09645 & 0.09632 \\
DFWS & -0.19202 & 0.089334 & -2.15 & $0.033^{* *}$ & -0.36871 & -0.01534 \\
cons & 2.026813 & 0.610156 & 3.32 & 0.001 & 0.820031 & 3.233596 \\
\hline
\end{tabular}

$\overline{* * *} \& * *$ show significant at $\%$ and $5 \%$ significance level respectively

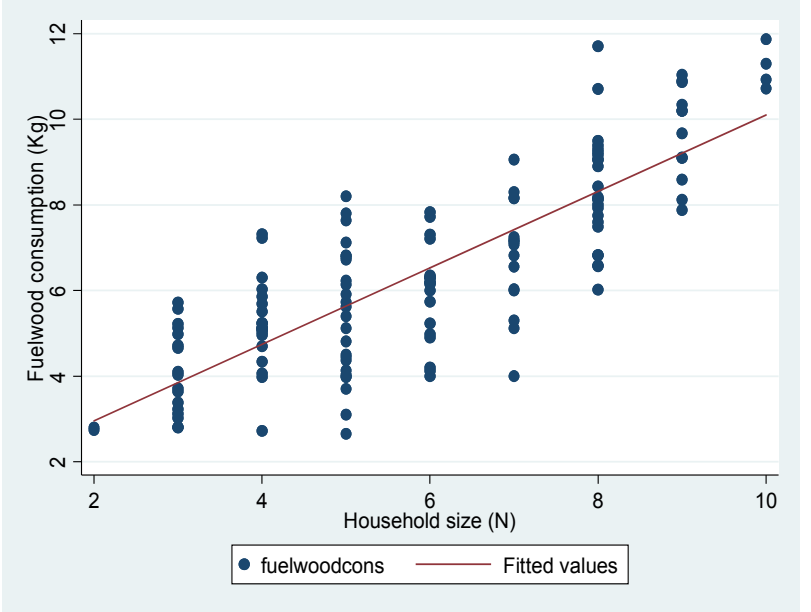

Figure 2. The relationship between fuelwood consumption and household size

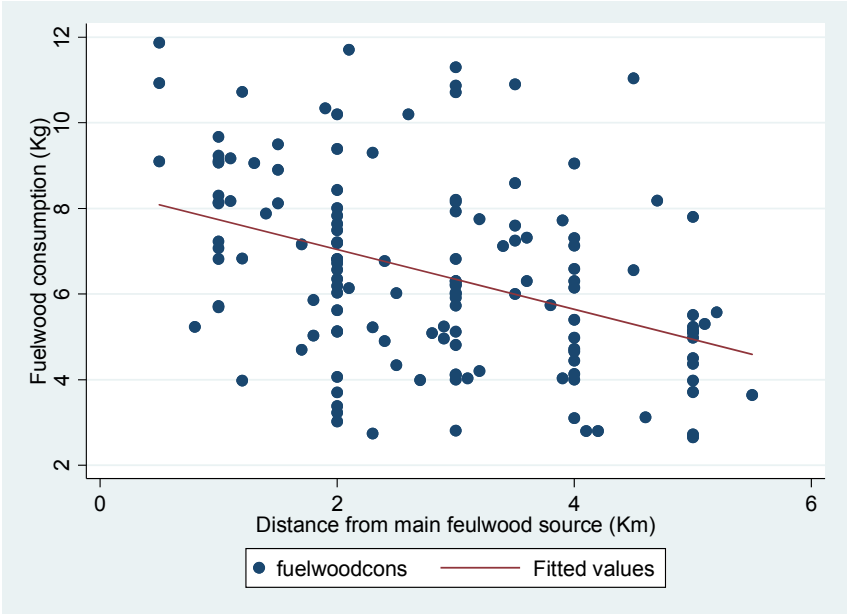

Figure 3. The relationship between fuelwood consumption and distance from fuelwood source

\subsection{Fuelwood source}

In the study area, the proportion of household's domestic fuel energy source for cooking and baking purpose was 
$57.47 \%$ from plantations (homestead plantation trees) as major source of fuel. $21.38 \%$ cow dung, $14.71 \%$ crop residual which is collected after farmers harvesting there agricultural crops mainly maize cane and cobs, and about $8.44 \%$ from illegal harvesting of natural forest (Figure. 4).

The results from households survey, Key informant interview, and field observation was found that from plantation forest Eucalyptus globulus was the most commonly used tree species $(72.1 \%)$ used for households domestic energy consumption which is followed by Acacia decurrens, Acacia abyssinica, and others like Eucalyptus camaldulensis, Vernonia amygdalina, Ricinus communis...etc. The main reason for using Eucalyptus globulus was associated with its fast-growing and better adaptive nature to the local agro-ecology, and furthermore most people in Ethiopia are dependent on the Eucalyptus as a source of fuelwood (Teketay, 2000).

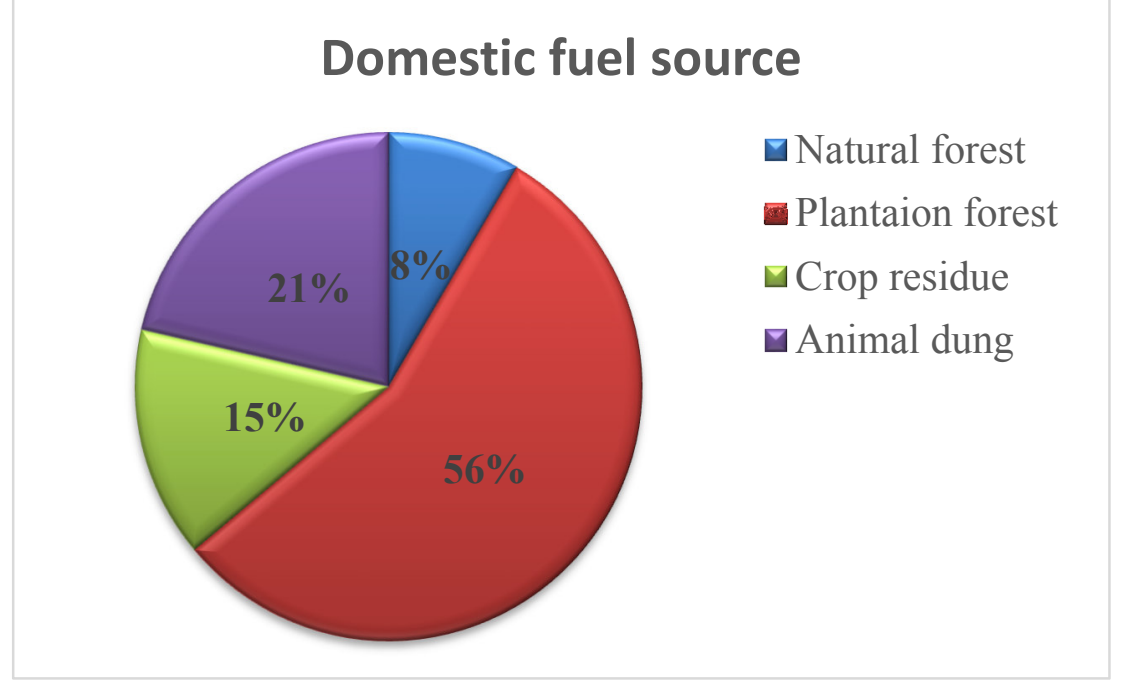

Figure 4. Source of traditional fuel for domestic energy consumption in the study area

\section{Discussion}

Fuel wood remains the main energy source for the majority of the people in Ethiopia. As compared to the situation in the past, the forest cover is now generally very sparse in the densely populated areas where rapid rates of deforestation and forest degradation have occurred due to the heavy demand on forest products, mainly fuel wood ( (Berhanu et al., 2017). Clearing forest areas to expand agricultural land and tree cutting for fuel wood, timber and agricultural implements were the main causes for the decline of forest cover in the region (Gebreegziabher, 2007).Household fuelwood collection has great impacts on changes of forest land cover types (Negasi et al., 2018).

The provision of wood energy is generally concluded to be a highly impacts to forest loss (Roubik et al., 2018). Forest biomass resources from private farmland (homestead) plantation are the main source of fuel wood in many rural areas of Ethiopian. Households with little or no land may face severe restrictions on access to fuels and some local communities harvest natural forest illegally for fire wood and charcoal production. Currently, Ethiopian government identified tree growing or afforestation, both at community household levels and as policy strategy to decrease deforestation and degradation, because of the deforestation that has occurred over many years scarcity of fuelwood is a critical problem in Ethiopia (Gebreegziabher and Kooten, 2013).

Socioeconomics characteristics, environmental characteristics and technology determinant factor for the household's fuelwood consumption. Household size is a significant variable that directly influence fuelwood consumption (Mekonnen, 1997; Ullah, S. and Tani, 2017; Ararsa, 2019). Household's residence far from fuel source affected the daily fuelwood consumptions. Moreover, fuel wood consumption is determined by the availability of fuel wood source for the local people. For example the people who have sufficient fuel wood inside their homestead or lived near by the forest utilized relatively more fuel wood than the other peoples. (Ullah and Tani, 2017). Subsequently, the easy accessibility of wood sources from the surrounding area are often increase the consumption of fuelwood and highly accelerate the rate of deforestation and forest degradation (Roubik et al., 2018). In the same while, the opportunity cost of collecting fuel wood increases with increasing distance to its sources away from home time consumed could be more for collection and harvesting less fuelwood. (Guta, 2014).

\section{Conclusion}

The finding of this study revealed that fuel wood consumption has negative impact on forest resource conservation and accelerate deforestation and forest degradation rate in the study area. The households energy source was found mainly from plantation forest specifically Eucalyptus globulus is the most common tree species for domestic energy consumption. In recent years the forest land coverage is changed to agricultural land and bar land due to 
population increment and highly demanded for forest products for energy purpose. This indicate even though forest is a renewable natural resource, its overuse can lead rapidly and straightforwardly to shortages. Household size and households residence distance from the main fuelwood source was the main determinant factors that affects households' fuelwood consumption in the study area. This study will help to design forest conservation by ensuring sustainable utilization of forest resource and assuring another alternative energy source for household domestic energy purpose. Providing another modern energies like electricity, solar energy, biogas and improving cooking stove application can decrease household's forest dependence and approved balanced usage of limited natural resource in the study area as well as all over Ethiopia.

\section{References}

Africa Renewable Energy Access Program (AFREAP). (2011). Wood-based biomass energy development for SubSaharan Africa: Issues and approaches. Washington, D. C.: World Bank.

Alemu, G. (2017). Role of biogas technology in forest conservation and carbon emission reduction in wondo genet district, sidama zone, southern Ethiopia. Msc Dissertation Hawassa University, Ethiopia.

Amigun, B. and Von Blottnitz, H. (2010). Capacity-cost and location-cost analyses for biogas plants in Africa.Resources, Conservation and Recycling, 55(1), pp.63-73.

Ararsa, D. (2019). Domestic biogas digester as a means of wood fuel consumption reduction in the rural households of Wondo Genet, Southern Ethiopia.

Bearer, S., Linderman, M.; Huang, J.; An, L.; He, G.; Liu, J. (2008). Effects of fuelwood collection and timber harvesting on giant panda habitat use. - Biological Conservation 141: 385-393.

Berhanu. N, Debela. H, and Dereje. B. (2017). Fuel wood utilization impacts on forest resources of Gechi District, South Western Ethiopia. Journal of Ecology and The Natural, Vol. 9(8), , pp. 140-150, August 2017.

Damte A, Koch SF, Mekonnen A. (2012). Coping with fuel wood scarcity: household responses in rural Ethiopia. Environment for development discussion paper series, EfD DP, 12-01.

Fantu, W. (2005). Above Ground Biomass Allomeitric Equations and Fuel wood Properties of Six Species in Ethiopia. Ph.D. dissertation, University of Putra, Malaysia.

Gebreegziabher, Z. (2007). Household fuel consumption and resource use in rural-urban Ethiopia PhD Thesis Wageningen University.

Gebreegziabher. Zebene and G. Cornelis van Kooten. (2013). Does community and household tree planting imply increased use of wood for fuel? Evidence from Ethiopia. Forest Policy and Economics, 34, 30-40.

Geissler S, Dietmar Hagauer PM, Alexander H, Michael K, Peter S,. (2013). Biomass Energy Strategy Ethiopia., AMBERO Consulting Gesellschaft mbH Immanuel-Kant-Str. 41, 61476 Kronberg i. Ts.

Guta, D. (2014). Effect of fuelwood scarcity and socio-economic factors on household bio-based energy use and energy substitution in rural Ethiopia. Energy policy, 75, pp.217-227.

H. Roubik, J.Mazancova, A.Brunerova and D. Herak. (2018). Factors influencing use of fuelwood and its environmental impacts in Tapanuli Utara regency, North Sumatra. Agronomy Research 16(S1), 1228 1236, 2018 https://doi.org/10.15159/AR.18.095.

Israel, G. D. (2012). Determining Sample Size, Agricultural Education and Communication Department, Florida Cooperative Extension Service, Institute of Food and Agricultural Sciences, University of Florida.

Kasim Adem Mohammed, Cherinet Seboka Ambaye and Kemal Nure Kawo. (2020). Evaluation of Fuel Wood Consumption and Its Implication to Forest Degradation in Agarfa Wereda, South-Eastern Ethiopia. Journal of Resources Development and Management Vol.62, 2020.

Macht, C and W. Axinn. (2007). Household Energy Consumption: Community Context and Fuelwood Transition. Michigan, USA, University of Michigan, Population Studies Centre, Institute for Social Research: 23pp.

Mekonnen A and Köhlin G. (2009). Determinants of household fuel choice in major cities in Ethiopia.

Mekonnen, A. (1997). Rural household fuel production and consumption in Ethiopia: A case study: Department of Economics, Göteborg University, Goteborg, Sweden.

Miles, L. and Dickson, B. (2010). REDD-plus and biodiversity: opportunities and challenges.

Ministry of Environment, Forest and Climate Change (MEFCC). (2016). National Forest Sector Development Program, Ethiopia Volume II: Program Pillars, Action Areas and Targets PP. 49(, MEFCC).

Mitku Alemu Mengistu and Yi Xie. (2020). mpacts of Livestock Holdings on Households' Decision to Participate in Wood Fuel Production from DrylandForest (Case study in Dire Dawa; Ethiopia). (d. 10.11648/j.ajere.20200501.13, Ed.) American Journal of Environmental and Resource Economics, Vol. 5, No. 1, 2020,, pp. 14-20.

Negasi Solomon, Hadgu Hishe, Ted Annang, Opoku Pabi, Isaac K Asante, and Emiru Birhane. (2018). Forest Cover Change, Key Drivers and Community Perception in Wujig Mahgo Waren Forest of Northern Ethiopia. MDPI Land 2018, 7(1), 32; https://doi.org/10.3390/land7010032.

Tatek D. , Berhane K. Tinsae B., Mihret S., Kibruyesfa S., and Eguale T. (2018). a Comparative growth performance of fast-growing tree species for woodfuel production in highland area of Ethiopia. Horticulture 
International Journal2018;2(6):309-316. DOI: 10.15406/hij.2018.02.00069.

Teketay, D. (2000). Facts and experiences on eucalypts in Ethiopia and elsewhere: ground for making wise and informed decision.

Ullah, S. and Tani, M. (2017). Fuelwood Consumption and its Impact on Forests in the Teknaf Peninsula on the Southern Coast of Bangladesh. 